KANUN VE KAZA (Geçen dergiden devam)

UCUUNCU FASIL

\title{
MUKABIL CEREYANLAR
}

19 uncu yüzynl sonlarına doğra bir muhalif hareket zuhur etti. Kanunun bogsluğu olmadiğı hakkındaki mutlakiyetle her yerde işin yürliyemiyeceği görüllü; bundan başka bazlaranın bu hükümranlıktan kurtulmak için saptıkları hileli yollar tehlikeli göründü. Bu, hakimin kanuna karşı olan vaziyetini tenkidi bir tetkike ve icabederse esaslı bir tadile tâbi tutmak lïzumunu hissettirdi.

Işbu aksiulâmeiin kökleri, yalnız hukuk ilmini ve adalet tevzii işlerini ilgilendiren değil de, bilâkis umumî medeniyet tarihinin bir parçası olarak kendini gösteren hâdiselerdedir(1). Kanun hakkındaki, hâkimin vazifesi ve onun kanuna karşı vaziyeti hakkındaki telâkkiler birbirinden müstakil değillerdir. Bunlar daha ziyade umumî kültür, etnik, sosyal ve politik telâkkilerle alâkalıdır. Ben burada yalnız en bariz unsurlara nazari dikkati celbedebilirim.

1. En önce son zamanların gittikçe artan ferdiyetciliğini ve subjektivizmini zilkredeceğim. 19 uncu yüzyll başlangıcı bir otorite devri idi. Prenslerin, devletin, kilisenin, objektif ahlâk ve adâbın, o vakitki cemiyet nizaminin otoritesi beserin düşüncesinde ve hareketinde hakim idi. Işbu otorite fikri en azametli felsefe seklini Hegel'in sisteminde ve en muhteşem ilmî tahakkukunu dokuzuncu Pi nin monarşik kilise teşkilâtında buldu. Lâyuhtilik akidesi otoritenin bir zaferi idi. Fakat bu otorite fikrine karşı modern ferdiyetçilik başımı kaldırdı. Spenser, Nice gibi mütefekkirler, Ipsen, Tolstoy gibi sairler bunu valz ettiler ve gittikçe genişieyen kitleler bunu tehalïkle kabul ettiler. Otoritenin naslar. na inanc, her sahada azaldı. Devlet tesisatına karşı olan tazim demokratik tenkitler ve sosyalist tahrikât sebebi ile eksildi; eski sıkı ahlâk inzibatı da mahsus bir sarsuntıya uğradı. Otoritelerin tenkidi, bir parola oldu. Fert artık körce itaat değil, itaatin sebebini, gayesini anlamak istiyordu. Bu suretle kanunlarn otoritesi zarar gördü. Kanunlarm mukaddesliği fikri, birçok yerlerde tamamen kayboldu.

2. Devlet telâkkisindeki tahavviuller işbu ferdiyetçilik fikri ile elele giderler. Bugün demokratik bir ruh geniş sahada, hatta monarşilerde hükïim sürmektedir. Bu fikir, modern esas teşkilât kanunlarn ile kabul edilen halkın kanun vazına iştirâkinin bir tabiî netiçesidir. Lüitfi ilâhi çelengi bundan böyle eski saşaasını kaybetti. Saltanat yerine ek-

(1) A. And. Heck, Gesetzesauslegung und Interessenjurisprudenz, 1924, s. 308; buna göre, hareket, surf hukuki meslek ilmi cumlesinden bir hareket olmalıdır. 
seriyet kaim oldu (2). Devlet tesisatına, devlet kanunlarına karș1 geniş mikyasta tenkit yapıldı. Devlet iradesinin yanıbaşında efkâr umumiye denilen irade gittikçe ehemmiyet aldı. Bunun dili matbuattır. Matbuat kendini, devlete karşı ve hükûmete karși, denebilir ki parlâmentodan ziyade halkın menfaatlerinin avukatl gibi hisseder. Gazeteler ve adliye ekseriya birbirlerine karsi gergin bir tavir takmurlar. Haksiz sayılan hükümlerin ve elverissiz sayılan kanunların tenkidi, gündelik ga; zetelerin en sevilen makalelerindendir.

3. Son on yllar içinde devlet, gittikçe artan bir mikyasta kültür ve içtimî yardım devleti olarak inkişaf etmiştir. Sırf hukuk devleti (gece bekçisi devleti) nin Mançester ideali ortadan kalkmıştır; bilâkis tekrar zabıta devleti (polizeistaat) fikrine bağlanılmıştır. Devlet müdahalesi daima hayatın daha genis sahasına sokulmustur, o kadar ki muidahalecilik tâbiri bir damga olabilir.

Gayet mânalı surette kanun şişliği (Gezetzeshypertrophie) denilen hal, devlet vazifelerinim bu genişletilmesiyle ilgilidir (4). Kanun ve kanuncuklar taşkın bir med halinde üzerinize dökülmüştür. Her işin ve herşeyin, kanunun her derde deva ilâcile şifa bulabileceği zannolunmuştur. Böylece kanum parmı, hiç de lüzumlu olmayan hallere sokulmuştur. Çok kere acele düşünülmeksizin, gelişi güzel teşri'eilik ve ya Isviçre'de denildiği üzere kanun mamulầtçılığı (Gezetzlimacherei) bunun memnuniyet verici olmayan bir neticesi idi. Bugünkï devletin her akla gelen bir maksat için kanun şeklinden istifade etmesi, etnik muhtevası ve esas bakımindan kuymeti son derece ehemmiyetsiz olan meselelerin tanziminde bu şekli kullanmış olması hali de buna inzimam eder. Son zamanın ortaya attığı döküntia kanunların sayısı az değildir.

Devletin bu tatbikatile kanunlarma karş bir hörmet temin etmediği gözönündedir. Kısa ömürlü, birkaç günliuk, değerinden ziyađe sıkleti ile nafiz olmak isteyen kanumlar bir otorite temin edemezler. Çok hakim olmak hevesi, hükûmet kuvvetini hususî bir hürmete mazhar kıImak için vasıta, çare olamaz: Devlet otoritesinin kuvveti, onun meriyetinin genişletilmesiyle elde edilemez. Itibar görmek istiyorsan kendini seyrek göster: Bu kaide burada da caridir. Yerinde olarak: Tanrnnın gü-

(2) Bak. F. W. Foerster, Staatsburgerliche Erziehung. 2 Aufl; 1914, s. 13.

(3) Bernatzik, Rechtsstaat und kulturstaat, 1912; Rosenthai, Wandlungen der Staatsaufgaben inden letzten Geschichtsperiode, Rektoratarede, Iena, 1913.

(4) Bak. Eggenschwyier, die Hypentrophle des Staates ind die Onnmacht des Gesetzgebers, Sehweiz. Juxisten - Zeitung, 1912, 337. 
nü odun kesmekte kullanilan kllicin harp için körleşmis olacaği söy lenmistir. (5).

4. Fakat yalnız devletin değil, cemiyetin münasebetleri de esasından değismiştir. Bütün hayat ve iktisat miunasebetlerinin sanayileşme tesirile olan tekâmuil ve tahavvülünü kaydedebiliriz. Iẹtimaî münasebetler bu tesirler altunda pek derin değişiklikler almıştır. Vaktile. hâkim olan sinıflar gerilemiş, yeni halk tabakaları ileri geçmiştir. Kuvvetli teşkilâtlar kendilerini tanitmağa çalışmaktadırlar. Her gün yeni hâdiseler, yeni ihtiyaçlar ortaya koymaktadir. Kalp, battal bir kanunla bu ihtiyaçlara ve icaplara ayak uydurulamaz. Kanun henüz istar edilmekle eskimiş ve yeni bir kanuna lüzum hasl olmus olur. Bir kanun ne kadar kazuistik ve teferruat a girişmiş olursa o kadar bu feci akibete maruzdur. Son on seneler içinde kanun, çok kere zamandan arkaya kalan, hakikî ihtiyaçlara artık uyamayan bir dưuma girmiştir. Böyle bir kanuna dayanarak vazifesine sadakatla hükküm veren hâkim kendine; hükmü haksız veyahutsevilen su tâbirle "dünyadan habersiz" dedirtmek mecburiyetine düşmüştür. Bilhassa mücerret (abstrakt) surette kaleme alinan bir kanunun gittikçe komplikelesen ve inee: farkłarla tecelli eden hayat münasebetlerine kâfi derecele uymadiğ ve aynı zamanda hâkimi de karşısına çlkan münferit bir hâdise hakkında o hâdisenin hususiyetine yakışan kararı ittihaz edebilmekten menettiği söylendi.

5. Teknik ve endüstride ve kezalik dünya münasebatunda; dinya ticaretinde, yukamda temas edilen inkisaf, aym zamanda iktisadilestirme, ticarileștirme, bir bakımdan Amerikanizm diyebileceğimiz bir düşünce tarzının büyümesine yandım etti (6). Bugünün düşüncesi siddetli bir ticaretçi, menfaatçi dủşünüştïr; işe yararlik ve verimlilik noktai nazarn en ön safta gelmektedir. Nasıl ki bir makine, cisimleşmiş bir işe yararlı arzediyorsa devlet ve hukuk da birçok salâhiyetli muhitlerde daha ziyade faydalan bakımından mütalâa edilmektedir (7). Artık es:

(5) Bak. v. Lann, zum Problem des freien Ermessen, in der Zitelmannfestschrift, 1918, s. 49: "On binlerce paragrafa bas vuracak olan ve hergitn çok kere en basit hukuk meselelerinde bile biłtün bu paragraflar tarafindan yuizlistü. birakilan kimse, kanun önïnde lïzumlu yulksek hörmet1 duyamaz..." Ermretmek manisi "Befehlswut" hakkinda F. W. Foerster s. 23, 27, 30, 32, 44, 49 ve sonrakilere bak.

(6) Bu hususta bak. Piloty, Reinische Zeitschrift 1914,.220; diğer taraftan Follwo, Risserfestschrift, 1913, s. 458 (?),

(7) Eggensehwyler a.a. O., s. 340: "Modern bir işletme müdürü için devlet git gide zamurl bir fenalık olmaktadır, hukuku, sadece istihsaìnin kalitestle öłçulen ticart bir işletme olsum veya boska bir işletme olsun: balt;, Stianmler; Thlearie: der Rechtsmiswenschaft; 1911; 8. 700. 
kiden olduğu gibi meri kanun, imanl inkiyad ile karşlanmıyor, bilâkis herşeyden önce kanumun neyi istihdaf ettiği, ne temin ettiği, ne faydası olduğu sorulmaktadır.. - Millî ve hususî ekonomik mülâhazalar - Ekseriya haddini aşarak ilk safa geçiyor. Sosyal düşünce denilen düşünceler evvelce olduğundan daha şiddetli kendini dinletmek istiyor. Bu düşünce tarzinı meslek halindeki hukukcular mahfelinde dahi nasıl yaylldiğt hakkında, modern yahut sosyolojik ceza mektebi denilen mektebin temayüllerine bir bakış, en göze batıcı bir manzara verir. - Evvelce pek galib surette ahlâkî noktaî nazar altında görülen - ceza bile bu mektebin mümessilleri tarafindan esas itibariyle cezannn neyi istihdaf ettiği ve neye faydasi olduğu istikametinde nazara alınmaktadır. Bunlara göre ceza hukuku, bir "cinayetle mïcadele hukuku" haline girmelidir.

6. Zamanımzzn diğer ve iftihara değer ioir hususiyeti de bu meyanda nazara alınmak lâzumdur. Bu da objektifliğe ve hakikata karş̣ olan gayrettir. Iģbu düşünce tarzında, şedit ölçüde zamana hakim olan tabiî ilim nesci, inkâr edilemez hassaya sahiptir (8). İ̧̧bu ciddi süssìz hakikate müteveccih tefekkür tarzan, skolastik hiurdacliklarla, bos, şekli talil (Formaldeduktionen) le, gayri hakikî faraziyelerle çalışmanın aleyhine uğraşır. Zamanımız gayri hakikilik ve samimiyetsizlik hakkında ince bir hissi haizdir; ve bunu mutlak surette takbih eder. Bu noktainazardan bakılunca hukukçularmn ananevi faaliyeti - gerek hâkim ve gerekse avukatın faaliyeti - bir takımına tamamile alkışa seza bir şekilde görünmemek lâzım gelirdi. Hususile, hukukî faraziye (Fiksion) açık bir hoşnutsuzluğu tahrik etti. Bir hâkim; kanun vazıl veya bir taraf "şüphesiz" (Offenbar) şunu veya bunu arzu etmiş̧tir diye bir tesbitte bulunursa güphesiz bunu arzu etmemiş olduğunu kabul etmeğe mahal olduğu acı bir istihza ile söyleniyordu. - Çok defa hâkim, bu gibi faraziyelere sığınmak için kanunun harflerine bağh olduğuna inandiğı taktirde kabulï tamamen imkânsiz bir neticeden nasıl masun kllınacağı teemmül edilsin.

7. Fakat yalnız tabii ilimden değil, mânevi ilimlerden de tenikidî ses. ler ve müsbet hareketler geldi. Burada programatik ehemmiyeti lâyikiyle taktir edilemiyen mânevî ilim cereyanını düşünmek lâzımgelir. Bu da 19 ncu yüz ylda klâsik Alman felsefesinin tesiri altında hüküm süren bir taraftan entellektüalizm'den ve mantikcliktan nefrettir. Bu cereyana, ye. niden daha ziyade iradeci olan, kısmen pek muhtelif ince farklara yer veren bir cereyan karş1 geldi(Rickert, Winderband, Wundt, Nietsche, Dar-

(8) Şliphesiz gölgeli tarafları eksik değildir. Tabii ilím bilgininịn değerden azade dưşuncesi, etnik hủkmil huvvetten düşürmek hususunda cok yardim etmiştir. 
win, Hartmann, Schopenhauer, Husserl gibi) ; bunların miussterek esas telâkkisi takriben şudur: Insan hayatında tâyin edici ve karar verici olan fikir (Intellekt) değil, irade (ve his ) dir. Insan sırf bir fikir makinesi değildir. Fikir dahi (hattâ ilmî fikir dahi) her hususta arzu (irade) unsurlariyle kuvveden fiile çlkamlır. Hükümler yerine taktirler kaimdir., kıymetten âri olan yerine kiymete itibar eden, hissi tebaruz ettiren (Emotionale, Gefuhlsbetonte) fikir kaim olur. Sonuncusumun sahasina bilhassa hukukî fikir de dahildir (9).

8.-Uzun on yıllar boyunca ihmâl edilmiş olan-Ahlâk ve hukuk felsefesinde bir yenilik, bilhassa eski tabiî hukukun faydah fikirlerini zamana göre yenileştirme temayülünün, işbu felsefî fikrin tahavviüïi ile bazl irtıbatı vardır. Yeniden uyanan felsefî fikir, çorak pozitifliğe karşı durdu. Felsefe sırf tescilden ve tesbitten bikmıștı, esas prensipler ve normatif noktai nazarlar tesisinden ve mevcudun (seienden) bu noktai nazarlardan taktiri yolunda gitmekten geri kalmak istemiyordu. Bu hususta başlıca Rudolf Stammier'i söylemek lâzumdir. Stammler'in doğru hukuk nazariyesi (1902), şu mesele hakkmda dikkati keskinleştirmek itibariyle bahsettiğimiz fikir sahasina dahildir: Bir kanun (yahut bir hâkimin kararı) objektif (sachlich) bakımdan ne vakit meşrûdur, mühtevâ itibariy. le doğrudur, âdildir. Bu mesele uzun zamandanberi lâyık olmadığı halde arka safa atılmıştı. Pozitivizm Fatalizm'e neyleder: O, mavaka'ı kabul eder, çünkü mevcuttur; fakat mevcudun tecrübe üstỉ norm'a vurularak, iyi ve doğrumu olduğu meselesini ya bir tarafa bırakır yahut baştan savma ve yanlıs mâlumatla cevaplandırarak: Amprik muta olanın veya tarihen var olmus olanm bundan dolayı normatif olarak da doğru olduğunu söyler. Bilhassa eski tarihî mektep bu noktadan ağır günah işlemiştir.

Tekrar ediyorum, son zaman başka türlü düşünmeğe başladı. Tarihî düşünce bugün kuvvetli değil-_hattâ korkulacak derecede zaynf bir inkisaftadır. Fakat bunun yerine zamanımız-tenkid'e karşı daima memnuniyetbahiş olmayan temayülden sarfınazar-inkâr edilemez surette tezahür eden hukukî hissin ve sosyâl adalet vicdanımın takviyesini karakterize eder. Bu zamanımızm bir iftihar sahifesidir. Halssız kanunlara ve hâkim kararlarma karşı belki hiçbir devir zamanımızda olduğu kadar hassas surette bir tepki hareketi göstermemiştir.

9 . Son olarak bizzat hâkim sınufı hakkında bir söz söylemek isterim. Hâkim sınıfı ananevî muhafazakârlıkla temayüz eder. Hâkimin

(9) Bak. H. Maier, Psychologie des emotionnalen Denkens, 1908. Lask, die Lehre vom Urteil, 1913. 
galip surette müteenni ve müteemmil olan faaliyeti, bu karakterini belki bürokratik terbiyesinden ve resmi itaat idsiplininden daha ziyade kolaylaştırır. Hâkim uzun müddet yeni zaman cereyanlarından gayrı mütessis kalmıştır. Fakat nihayet hâkim de kendini onlardan âzade kılamamıştır. "Dünyaya yabancı" mahkeme kararları diye daimî surette yapılan istihfaflı tenkidler ve bazı yerierde dahi hâkimin istiklâlini müzakere mevzuu yapmak hususunda yukandan doğru vâki teşebbüsler hâkimleri bizzat şahıslan ve vazifelerinin şerefi noktasından düşünmeğe sevketmiştir. Bu suretle yakın mâzinin tamamen kendine mahsus hâdiselerinden olmak üzere bir hareket zuhur etti; maksadım Avusturya ve Alrnanya'da yapılmış olan hâkimler cemiyetlerinin tesekkülünü söylemektir(10). Bu teşkilâtta demokratik temayüllerin bir ifadesi, birlik halinde bizzat ihkakihak maksadiyle tesis edilen hey'et lerin bir kopyası görülmek istenmiştir. Bunda isabet olduğunda ben kuvvetle mütereddidim. Her halde: mutlak devlette böyle bir serkeşliğe tahammül edilmezdi; kezâlik buna cür'et bir hâkimin fikrine güçce gelirdi. Bunula beraber modern hâkimler cemiyetleri kendilerini bir serkeşlik töhmeti altına sokmak arzusundan pek uzaktır; bu cemiyetler yalnız kendi makbul ve müeyyet saydıklar hukuka istinat etmektedirler. Bu cemiyetlerin maksatlarının samimiyetinden şüphe etmek ağır bir hata olurdu. Bilâkis bu cemiyetlerde hâkimliğin mahiyeti hakkmda değişmiş olan bir zaman telâkkisi ifade edilmektedir. Bunları sendikalarla bir tứmak da hiç olmazsa sakattrr. Hâkimler cemiyet̂lerinin esas ve has gayesini, derece ve maaş meselelerinin hâl ve tesviyesi teşkil etmez. Bilâkis onfarı ötedenberi başlıca dikkat ettikleri şey hâkimlik mesleğine karşı haksı tecaviuzlere ve istiklâllerinin gayrı lâylk surette tahdidine karşıı müdafaa idi (11). Kâkkimier elele vererek kendilerine haksiz surette memur karakteri izafe edilmesine karş koymuşlardır. Hâkimler cemiyetleri, bihakkm her şeyden önce hâkimler kanunu ve bilhassa hâkimler için mesai nizamnameleri meydana getirilmesini kendi programlarına ithâl ettiler. hâkimler cemiyetleri kendi beyannamelerinde hâkimlerin idarî memurlara karşı daha ihmâlli tutulması hakkında şikâyette bulunurlarken dahi ilk safta rütbe ve derece emelleri gibi maddî saiklar altında hareket etmemişlerdir; bilâks onları harekete getiren daha derinde mevcut bir unsur, yâni hâkimin yüksels fonksyonunun, idare memurlarınm fonksyonuna haricen dahi tamamen

(10) Bak. Avusturya hakimlerinin tesis beyannamiesi Eurkharard da, der Richter, 1909 s. 29

(11) Reichel, Recht und Wirtschaft, 1912 s. 2 
miäsavi klymette kabul edildiğini görmek arzusudur. 'Gene bu harekette âmil, jdare memurlarına kabul oluman serbest taktirde simdiye kadar olduğundan daha buiyuilk bir hisse sahibi olmak hasreti olabilir(12).

\section{DÖRDUNCÙ FASIL}

\section{Hâkimin vesâyetten kurtulmaș. (Emanzipation)}

Yukamda kanunun her şeye kifayeti hakkında ki şimdiye kadar.meveut nazariyelerin yeni bir tetkikini icabettiren en mühim fikrkictimaî hareketlerin taslağı yapılmıştır.

Zemin bu suretle hazırlanmıs oldulttan sonra tâze ve zengin bir tohum yeşerebilirdi. Muhtelif şekildeki yazılar derhâl yeni meselerle meşul oldu.

Bu babdaki eserlerden hepsinin burada saylmasın beklememelidir. Ancak en göze çarpan neşriyat kısaca zikrolunacaktur. Bununia beraber bir kısım nesriyatın fazla ve bir kısmın daha az dikkati calip olđuğu meselesi noktasından birçok fikir ihtilâfi olabileceğini söylemeğe hacet yoktur. Bazısının zevke göre belki az ehemmiyetli olanın çok, daha mühim olanm pek az ẗzerinde durulmuş olacaktır. Bu noktamın hiç bir tesiri yoktur.

I - Evvelemirde umumiyetle "serbest hukuk mektebi önderleri" sayılan bir takım müellifleri hatırlamak icabeder.

1. Bunlar arasında zamanen birincisi Rudolf thering idi Bu mühim adam jlkinde tamamen ananevi doktrinin mümessili idi. Roma huhukukun ruhu (geist des Römischen Reckts) (13) adl eserinde-ki en kızgın hasmı dahi havi olduğu birçok ince fikirlere itiraz edemez - Konstruksiyon kazasına (Konstruktions jurisprudenz) "Hukuk, hukuk içindir" yolunda estetikleştirme istikametine hayli zaman için son büyük bayrammı yaptı. Bizzat thering bilâhare bu noktainazara sadakatta bulưnmad1. Nasıl ki tabiî hukukdan tarihî hukuk telâkkisine intikal, en açık surette Fichte de görülebilirse kanunun mahiyeti hakkında eski telâkkiden yeni telâkkiye intikal de en iyi surette thering'de takip edilebilir. thering'in sonraki senelerinde, gençliğinin rüyasını yanlıs bir

(12) W. Jellinek, Gesetz, Gesetzesanwendung und Zweckmässigkeitserwägung, 1913, s. 7: "Hâkim idare menurundan daha serbesttir,çünki o yalnz kanuna itaat eder, ilst mercie de itaat etmez. tdare memuru hakimden daha serbesttir, ciunkt idare memuru, "hakkimden daha çok serbest taktir dairesinde hareket eder. " - Bak. keza Boasson, de rechter tegenove de vrijheid der administratie, Groningen 1911.

(13) 4/5 Anfl., 1881 bis : 1801. 
göz boyası gibi anlaması ve hulkuk ilmine yeni bir istikamet gösterme uğrunda cidden uğraşması büyük bir fikri cevvaliyete ve cesur bir karaktere delâlet eder. thering hukukun mefhum semasiyle alay etmeğe ve onun balçıtan sanemlerini tahtından indirmeğe cesaret eden şahıs idi. Ve o, bu menfi vaziyette kalmadı. Onun aslen müsbet olan ruhu, bilâkis hukuk ilmine müsbet bir mesnet amyordu ve bunu, hukukun gaye münasebetlerinde (Zweckzusammenhänge des Rechts) buldu (14). "Gaye bütïn hukukun halıkıdır". Issbu,bir devir ifade eden sözle thering suietfehhümden âzade surette eski tabî hưuka tekrar iltihak etmiş ve aynı zamanda modern gayevi hukuk ilminin müessisi degilse de en mühim bir pişdam olmuştur. Fakat şüphesiz: Onun en meşhur eseri olan "Hukukda gaye" haricen olduğu gibi dahilen de nâ tamam ve bundan dolayı tat. mine kifayetsiz kaldı. thering zamaninın çocuğu idi ve bütün dehasiyle beraber gençlik tahsilinin noksanlamn yenmege bir daha muvaffak olamadı. Onda esaslı bir felsefe tahsili noksan idi. Felsefe mütehassıslam bunu tekrar tekrar ortaya koymuşlardır. Bilhassa onun Etik'i derin bir temelden mahrumđu - ki bu temele dayanmaksızun başka türlü nasıl hukuk felsefesi yaplabilir? - Bu Etik, zavalh bir menfaatciliğe(Utilitarismus) saplandı kaldı. Jhering'in hukuk felsefesi, hukukun parlak bir teknolojisidir; ahlâki temeli ise zayıf ayaklar üzerinde durmaktadır. Bu temel, (Ictimaî egoizm hizmetinde) maI ve menfaat himayesi fevkine asla çıamad.. Jhering, keza "Gaye" nin Jhering'i bu kelimenin felsefî mânasiyle pozitivist idi ve böyle kaldı. Onun smmrlar kâfi derecede bu suretle gösterilir. O, arzl-mevud'a ancak uzaktan bakabildi. Fakat biz onun serefini azaltmak istemiyoruz. Çünkü bu arza karş, ilk ve en ciddî biri olarak bütün hayatmea hasret taşıyan ve bu hasretle, kendi kadar büyük olmıyan diğer binlercenin de kalbini ateşliyen o idi.

2 . Ince fikirli ve sevimli Dernburg, Jhering'in fikir akrabasıdrr. Bütün yazilariyle, bilhassa bas eseri olan Das preussische Privatrecht ile yalnız menfaatci bix gaye uygunluğuna değil, belki daha fazla olarak ictimaî adalete de ihatalı bir nazar attı. Bu adaleti, hattâ direnen metne karşı dahi muzaffer kılmak için Dernburg, tam mânasiyle hiç yılmamış ve kararlarindan bâzılam hattâ bâzı serbest hukuk havarilerinin ittihaz edebielcekleri kararlardan "daha serbest hukukcu" kararları olmuştur. Mektup kanunun kifayetsizliği, ona olduğu kadar az kimseye meş'ur idi; ve filhakika Dernburg has bir nüfuzla kanundan başka - çok aleyhinde bulunulmus olan -işin mahiyeti (Natur der Sache) nin da hukukun menbal olarak tanınması lâzımgeldiği hakkındaki eski tabiî hukuk ka-

(14) Der Zweck'in Reht, 2 Aufl., 2 cilt, 1884 bls 1886. 
idesini tekrar vâzetti. $O$, felsefe 1şlklarından da mahrumiyetin caiz olmadığı fikrinde idi. Acaba Dernburg'ın felseye derin bir âşmalı̆ı varmiydi? Bunda süphe edilse sezâdır.

3. Sira Dernburg dan daha cessur ve daha ileri Josef Kohler'e gelmiştir. Fransız Rein hukukunun daha serbest havasında yetiģmiģ olarak ateşli mizacı icabı her tür!ü mütasallifane bağlluktan kaçan Kohler, daha genç yaşlarında gerek nazarî ve gerek amelî bakamidan kanunun serbest tatbiki taraftar oldu. Kanunun tefsiri hakkındaki ufak tetkikinde (Grinhut 13, 1 ve sonrakiler) (15) daha yeni serbest hulkukcular tarafindan ilân olunan bütün fikirler hị olmazsa esas itibariyle bütün vüzuhu ile beyan edilmiştir. Kanunlar kanun koyanın iradesine göre değil, belki işin mahiyetine ve küItüir vaziyetinin icablarına göre tefsir olunmak lâzımdır. Külttür vaziyeti değismiş olursa aynı kanunun tefsiri de o dairede değişmek lâzımgelir. Kanunun tefsiri, bir intibak ettirme, bir kültür siyaseti işidir. Şüphesizdir ki Kohler serbest hareket cereyanı denilen cereyana iptidadanberi hararetli bir alâka göstermiştir ve onun mümessillerinin mütalâalariyle esaslı noktalarda bir olduğunu ilân etmiştir(16). Hattâ bir dereceye kadar Kohler'i serbest hukuk hocesı olarak göstermek caizdir. Bazlları tarafından, hâikimin muayyen icaplar altında kanun hilâfina dahi hüiküm verebileceği yolunda konulan modern nazariye ile Kohler, șüphesiz hic olmazsa daha önce, aymı fikirde değildi. 0 bilâkis -daha Porzia'nın kazası(Richterspruch) hakkundaki sözlerinde buna işaret etmiştir-hâkimin ledelicap kanuna mutabakat zevahirini muhafaza ederek kanunu bir dereceye kadar aşağıdan doğru "oyması", "fena esbabı mucibe ile iyi hükümler vermesi" icabettiği fikrinde bulunmuştur. Kohler'in bù talâkkiyi bugün dahi muhafaza ettiğinin farkında değilim. Böyle olmadığmı zannederim.

4. Erich Danz, mektup kanunun kifayetsizliğine ve kanundan başka halkın talâkkisinde ve teamüllerde tezahür eden örf ve âdet hukukunun dahi nazara alnmasi mübrem bir zaruret olduğuna müteaddit eserlerde

(15) Keza bak. Jherings Jahrbücher, 25, 262 ff(über die rechtsschøpferische Kraft der Irisprudenz). - Kohler'in tefsir nazariyesiyle Wach'in tefsir nazariyesi akrabadir. Bak. Handbuch des Zivilprozesses, I, (1885) $254 \mathrm{ff}$.

(16) Bak. Goltdammers Arsehiv, 60, 108 : "Aşikârdır ki... Tatbikatçıların yeni mektebi tarafından istenen ģey, benim yllarea evvel ogretmiş olduğum, fakat vaktiyle onlarn Windscheid'an koyduğu esastan ayrilmak istememelerinden ve bundan başka ilmi mesâtien daha ziyade şerhleri okumağ itiyad etmelerinden dolayı kabul etmek istemedikleri bütin hususlarin kabul ve icresından baska bir şey değildir. Fakat bu kabulü bugiun belkliyebilitim. 
(17) işaret etmiştir. Teamül ve örf ve âdet hukukunun birbirinin aynI sayması doğrumudur değilmidir keyfiyetini tekik yeri burası değildir; kat'i olan, Danz'in örf ve âdet hukuku meselesine yeniden ehemmiyet atfı lüzumuna israrla tekrar işaret etmiş olmasıdır. Bundan başka Danz son zamanda kanunun gayevî vazifesini ve onun gayeden tefsiri lüzumunu daima yikselen bir sesle söylemiştir(18).

5. Rudolf Stammler(19) kant'un düşünüş̧ yollarında giderek tarihî hukuk nazariyesi metodunu şiddetli bir tenkide tâbi tutmuş, daha ziyade tabî̀ hukuku tekrar elé almış, onun tarihî olmayan telâkkisini, metodu hukukî irađenin tarihî sebeplerden ileri gelme münferid mühtevâlarindan şuurlu surette vazgeçmek olan formel bir tenkit usulưne müracaat ederek tashih etmiştir. Stammler mevzû hukuk ile doğru (hakkaniyete uygun) hukuk arasında derin bir fark olduğuna lâyık olduğu ciddiyetle işaret etmiştir. $\mathrm{O}$,yalmız bütün mevzû hukukun doğru hukuk olup olmađłğımm tetkiki lüzumunu iddia etmeyip hâkimi kaabil olduğu kadar mevzû hukuku, vereceği hükư̈m doğru ve hưkuk kaidelerine tevafuk edecek mânâda tefsir etmeğe de mecbur tutmuştur. Stammler, serbest hukuk nazariyesi denilen nazariyeye de icabet etmemiştir (aşa. Beşinci kısım II bak); bazı serbest hukukcular tarafından öne sürülen hisse uygunluk (Gefuhlsmässigkeit) unsuru, hakikatta onun aklî(intellektualistisch)istikametindeki esas talâkkisiyle hemahenk olamazdı. Stammler'in yazılarınm hâlihazırda yürüyen fikir cereyanları üzerinde kuvvetli bir tesir hissesi bulunmadığını zannetmek pek yanlış olurdu. Yukarda ùçüncü fassl 8 de işaret edildiği üzere Stammler'in kanun tenkidi adalet vicdanmm.(Gerechtigkeitsgewissen) incelmesine ehemmiyetli surette yardım etmiştir. Diğer taraftan Stammler'in bizzat kenđi doğru hukuk"Praxis" inde verdiği bazı kararlairn, asil serbest hukukcular tarafından dahi üstün gelinemiyecek derecede kanunun metnine karșı cüretkârlı̆̆ın anlamak için tetkikine ihtiyaç vardır. Hakikatta çok defa serbest hukuk yolunda giden müiellifler, prensip itibariyle Stammler'in noktai nazarından uzak kaldıklarmı zannedi-

(17) Auslegung der Rechtsgeschäfte, 3 Aufl. 1911; Laienverstand und Rechtsprechung, 1898, Rechtsprechung mach der Volksanschauung und nach dem Gesetz, 1908; Einffilrhrling in die Rechtsprechung, 1912; Richterrecht 1912.

(18) :Bak. Nachruf von Niedner, Schweiz. Jur. Ztg. 1914/15 s. 180 . Kornfeld (Soziale Machtverhältnisse, 1911), Danzvari efkar jle bir derece akrabalık arzeder(bu bapta Reichel, Lit. C. Bl, 1911, 989). Keza bak, Rolin, Prolegomènes à la science du droit, 1908 (bu bapta Reichel, Zeischrift für philosophie und philosophiche Kritik. 145,201).

(19) Die Methode der geschlchtlichen Rechtstheorie, 1888; die Lehre vom rich tigen Recht, 1902; (bu bapta Retchel, Zeitschrift fur philosophie und philosophische Kritik, 124, 232); Theorie der Rechtswissenschaft, 1911. 
yorlarsa da neticede onun hâl tarziyle tamamen ittifak halinde olduklarinı görüyoruz(20).

6 . 1885 ylinda Oscar Bülow'un Leipzig Universitesinde Rektörituk hitabosi inti̧̧ar etti. Bu hitabe hâkimin kanun ile münasebetine dair bütỉn söylenmiş olanların en ehemmiyetlisidir(21). Bu eserin öziă, bir mücerret kanunun yalnız başına hukukî hayatı kat'i bir muayyeniyet ile tanzime kâfi geleceği hakkmndaki akideye 'karşı mücadeledir. Bülow diyorki bilâkis daima, kanunun umumiyet ihtiva eden emri, hâkimin münferit hâdiseye taalluk eden fonksionu ile konkreleştirilmeye mühtaçtır. Bu itibarla yalnız kanun vâzı değil, hâkim de hukuk yaratma işinde faaliyette bulunur; hukukun yaxatilmasmila, kanun vâzıl umumî bir tasar ve plân vermek, hâkim de tatbik ve inşâ'da bulunmaksuretiyle iştirâk ederler. YaInız kanun değil, kanun ve hâkimin faaliyeti bir arada halka,kendi hukukunu temin ederler. Bu suretle Montesquieu'niun akidesi esas itibariyle ortadan kaldırilmıs oluyor. S̈üphesiz hâkim kendini, kanunun umumí emrine herhalde bağl tutmosidır;Bullow, baz serbest hukukcularm taleblerinden asla haberdar olmak istemez(22).

7 . Gustav Rümelin'in"Werturteile und Willensentscheidungen"hakkındaki fatînane kançler hitabesi bu rektörlük hitabesine kıymetli bir teyit teşkileder (1895) (23). Birçok sahalarda maiûmat sahibi olan bu müellif diyor ki hâkimin, kanunu tatbik işinde, surf bir hâdiseyi kanundaki kaide altına koyucu bir mantık faaliyeti icra ettiği, sırf bir deduksion otomatı olduğu hakkłundaki fikirler tamamiyle yanlıştır. Bilâkis hâkim. sayısız bir çok hallerde, bilhassa en mühim hallerde kıymet hükümleri verir; bunlarda kafanın daha az, hissin, yâni etik klymet taktirlerinin ișe daha çok roliu vardır. Bir mebiin esasll ayıplam nedir? Bir mukavelenin feshi için mühim sebep nedir? Mükellefiyetlerin ağır surette ihmâli nedir? Bunlar sırf aklî istidlâl ile kendilerinden hiçbir şey elde edilemiyecek olan klymet mefhumlamdir(25).

(20) Kohler ve Stammler arasinda bir Syntes, Britt tarafindan tesbit edilmiștir, Kunst der Rechts: anwendung 1907 (Bu bapta Lit. .C. Bl. , 1907, 1536, Reichel)

(21) Gesetz und Richteramt, 1885. Bulow un telakłzileri Wundt'un hukuk felsefesi üzerine kuvvetli tesir icra etmiştir.

(22) Recht, 1906, 769

(23) Bak. Juristische Begriffsbifdung, 1878.

(24) Reizler, venire contra factum proprium, 1912, adj eserinde êok ileri giderek şöyle diyor: "hukukta serbesti taraftarlamnı usul noktosından açmış, oddukdarı şiddetli mínakaşa neticesinde daimi bir kiymeti haiz olmak tzere elde edilen hakikat, kanaatımıza bu ... nutkun sukunetli bir objektifligi scinde:zaten yer almustır. Filhakika ayn derecede mühim bir takım noktalar oroda bahis mevzuu edilmemiştir. 
8. Son zamanlarda Karl Wieland'n üstâdane sâde,vâzłh ve objektif rektör hitabesi buna benzer temayüller gösterir (25). Romelin ve diğerleri gibi Windelband-Rickert kültür felsefesinin tesiri altında Wieland,tarihî mektebin tadsızlıklarma karş̧ ağır sözlerle yürümüs, tarihî mektebi yanlış bir tarihcilik ile tavsif etmiştir. Bir hukukun ilmî surete anlaşılması ancak onun tarihinden-istihrac edilebileceği hakkında ekseriya kuvvetie ortaya konan tez (26) isbat edilememiş ve isbatı imkânsız gëruilmüş̧ür. Tarih felsefesi, bilâkis bunun ałzsini tâïim etse gerektir. İlmî bir tarih yazısı fevkattarih değer öIçüleriyle meşrut olmalıdır. Filhakika bu ölçüler olmaksızm her hangi bir intihap prensibi olamaz. Bu itibarla bir hukukum taktiri için kıymet ölçülerini, bizzat onun tarihinden çıkarmak arzusu bir devri-fâsit olur. İ̧̧bu yanlış tarihî metoda karşıı bilâkis, ahlâkî-gayevî istikamette hareket eden hukuk ilminin bir "tenkidî metodu" himaye,müdafaa edilmektedir.

II . Simdi assl "serbest hukukculara" dönelim. Serbest hukuk mektebi, o ehemmiyetli hareketin en ön mevkiinde bulumur. Bu harekete iltihak eden herkes serbest hukukcu da değildir; biraz önce isimleri zikredilenler-belki Kohler müstesna—serbest hulkuk mektebinin iddialarmdan uzak kalmıslardır.

Evvelemirde bu mektebin tesmiyesi hakkında bir iki söz söyliyelim. "Serbest hukuk" hareketi sözü "dinde serbesti" (freireliğiöse) hareketi tâbiri örnek tutularak meydana getirilmiştir. Bu tâbir zevkli değildi. Dinî bakımdan serbest düşünen kimse, serbest dindar, serbest düşünüşlü demektir. Fakat ne veyahut kim serbest hukuka mensuptur? Ve esasen "Serbest hukuk" (freies Recht, freirecht) nedir? Ben bir serbest hukuk taharrisi, bir"serbest hukuk ilmi"'(Ehrlich), yâni bazı bağlardan ve meselâ kanun bağlarmadan âzâde bir kaza, bir hukuk ilmi düşünebilirim. Bunun bir mânasıı vardır. Fakat bir serbest hukuk altında herkes istediği gibi düsüunebilir. Bunumla bereber ne olursa olsun serbest hukuk, serbest hukuk hareketi tâbiri bir kere yerleşmiştir ve bu emrivâkii nazara almamak mâkul olmaz.

1. Işbu mektebin zamanen illk mümessili olarak Avusturyalı Eugen Ehrlich den bahsetmok lâzmgelir(27). Kanunun boşluktan âzâdeliği hakkındaki akide ilk önce onun tarafindan esash ve cesurane bir tenkide tâbi tutuldu. Kanun neredeki bir hüküm ihtiva etmez ve tefsir yolu ile de

(25) Historische und Kritische Rechtswissenschaft 1910.

(26) Gierke, Die historische Rechtsschule und Germanisten, 1903, s. 7 1903

(27) Lücken im Rexht 1888, freie Rechtsfindung und freie Rechtrwissenschaft. 
böyle bir hüküm istinbat edilemezse orada, Ehrlich söylüyor, bir boşluk vardur, bu boşluk hak ve nasafet, ex bono et aequo mülâhazaları altında đoldurulmak lâzımdır.

2. Bunu müteakip Gény (28) ve Lambert (29) Fransa'da buna benzer fikirlerde bulundular. Kanunun ve örf ve âdetin herhangi bir hâkim kararmun ıstarı için kâfi bir esas olacağın zanmetmek bir hatadır. Bilâkis bunlardan başka geniş mikyasta bize hukukî hâdisenin, işin mahiyeti, adalet ve ictimaî gayeye mutabakat dairesinde hallini gösteren serbest ilmî fikir mevcuttur.

Burada Fransız hâkimi ve onun kanuna karß̧ı vaziyeti hakkında ve istitradi bir mülâhazaya yer verilebilir. Fransız hâkimi, başta Paris Kassation mahkemesi uzun zamandanberi kanuna karşı, Alman, Avusturya hâkiminden mühim surette daha serbest bulunmaktadır. Bu bapta âmil, Kod sivil'in liberal vaziyeti idi. Prusya umumî memleket hukuku ile Fransiz Medeni Kanunu arasindaki tezattan daha büyük bir tezat bulunamaz. Prusya kanunu, hâkimi sayısız münferit hükümlerin ince örülmüs ağına soktuğu halde Kod sivil birkaç icazlı düsturlarla iktifa etmiş ve bütün geri kalanı büyük itimatla hâkimin taktirine birakmıştır. Böyle bir hareket tarzonda Frederik sisteminde olabileceğinden büsbuitün başka bizatihi șuurlu bir hâkim sımfının yetişeceği apışikâr bir keyfjyettir(30).

3. Almanya'da Fransiz modeline bilhassa nazarn dikkat atfedilmesi beklenebilirdi. Fakat bu, ancak nadiren vukubulmuştur. Hattâ Reich mahkemesinin Rein senatosu hükmünde bu numuneye imtisâl edildiğinin pek az bir izine tesadüf edilmiştir. Bilâkis Alman hâkimi önüne Ingiliz numunesi bir ayna gibi komuldu. Bu talakkkinin hatibi Franz Adickes idi. Henüz genç bir stajiyer olarak turfanda bir yaz neşretti ve bunda kanun ve örf ve âdetten başka aym neviden üiçüncü hukuł menbal olmak üzere işin mahiyetinin de ehemmiyeti olduğunu izah ediyordu(31) ( Fakat işin mahiyeti, ancak hâkimin süpjektif hukuk hissi hakkında objektif bir ifade ihtiva eden bir tâbir olacaktır. Adickes işbu serbest gidişli hukuk

(28) Méthode d'interprétation et sources en droit 1899 (Saleilles in klassik ön sözth ile), Science et technique en droit privé positif, 1914. Geny'nin tesiri altunda: v. d. Eycken, methode positive de l'interpretation juridique 1907.

(29) La fọction đu droit civil compare, 1908.

(30) Fransız hâkimi Magnaud, Sulleymanvâri hakkaniyet huklimleriyle bir dereceye kadar işth̉har etmiştir. Bunda Fransız hakim tipini gormek şüphesiz ters bir görtiş olur ve onun zeki vatandaşlarn tarafından en az tasvip edilirdi. Esasen Magnaud mizacinda birkaç hákim her memlekette bulunur.

(31) Zur Lehre von den Rechtsquellen, 1872. Bak. Bischoff, Die Natur der Sache als Rechtsquelle, 1895. - Buna benzer fikirler için Schlossmann, Der Vertrag, 1867; Der trrtum liber wesentliche Eigenschaften, 1908. 
hissi idealini bilâhire Ingiliz hâfkiminin hükümlerinde müşahhas olarak gördü ve Ingiliz mahkeme teşkilâtını Almanya için taklide şayan bir nümune olmak üzere göstermekten yorulmadı(32). 0 , karar ve hüküm vermenin akll işinden ziyade kaip ve karakter işi olduğunu söylüyordu; yâni ona göre evelemirde Ingiliz nümunesine tevfikan serbest ve müsta. kim hâkim şahsiyetinin, hâkim kral (Richter König)'in yetiştirilmesi ve intihabı gerektir. tigiliz hâkimi hakikaten Adickes'in ona izafe ettiği işbu pretorvâri imperyumdan memnunmudur; yoksa bilâkis sabık emsâle merbutiyet suretiyle ve İngilterede kara Avrupasından çok kuvvetli olarak inkişaf etmiş olan anane kuvveti ile daha fazla bağh durumda değilmidir? Bu bahiste bu meseleye daha yakıdan temas edilemez(33).

4. Adickes münakaşa noktasını daha ziyade âmme sahasına, yâni mahkemeler teskilâtı hukuku sahasına koymaktadır. Esas itibariyle bir devlet hukukuna ait noktai nazar Spiegel izaheder(34). Umumî hukuktaki (Gemeinrechtlich) tefsir nazariyesi, ona mutlakiyet devrinin "Mutlakiyet Devletinin" Mart öncesine ait tab'a itaatmin bir mirasıdur. Bu nazariyeye bağl kalan kimse, bununla devlet mutlakiyetini kabul eder. Bu talâkkiyi Spiegel siyasî olmak üzere artık zamana uygun -saymaz.

5 . Serbest hukuk mektebi içinde hususî, ayrı bir grubu da menfaat jürisprudansı denilen kazanin mümessilleri teskil ederler. Bilhassa Stampe (35)' Heck (36) 've Muller-Erzbach (37)'s zikrederim. Bu müellifler terkip metodunu (Konstruktions methode) katiyyen ret etmek suretiyle düstur olacak kaza prensibini, hukuku müdafaa ile muvazzaf olan devletin de dahil olduğu alâkadarlarnn tipik menfaatlammn muvazenesinde görürler. Kanun hilâfına hükü̈m salâhiyeti ancak fevkalâde zaruret hallerinde, ictimaî bir garabetin mevcudiyeti halinde ve ancak hususî tahdit ve şartlar altında tecviz edilir. Böyle bir halde garabeti olduğu gibi göstermelidir; dar tefsir zavahiri altında gizleme ve buna benzer hareket

(32) Stellung und Tätigkeit des Richters, 1906; Grundlinten durchgreifender Justizreform, 1906.

(33) Bak. Mendelssohn-Bartholdy, Das Imperium des Richters, 1906; Gerland, die englische Gerichts verfagsung, 1912; Reichel, Lit. C. Bl. , 1910, 685; Kiss, Archiv für burgerliches Recht, 1913, 265; Hirschfeld, D. J. z. , 1914, 162.

(34) Gesetz und Recht.

(35) Unsere Rechts und Begriffsbildung, 1907; die Freirechtsbewegung, 1911; Grundrise der Wertbewegungslehre, 1912 (bu bapta Reichel Lit. Bl. 1913, 530).

(36) Das Problem der Rechtsgewinnung, 1912; Gesetzesauslegung und tnteressenjurisprudez, 1912; bak. D. J. Z. , 1905, 1140.

(37) Gefuhl oder Vernunft als Rechtsquelle, 1913; Die Relativität der Begriffe und ihre Begrenzung durch den zweck des Gesetzes, 1913. 
tarzları mürailik olarak damgalanır (37)*

6 . Bilhassa Windelband-Rickert nüfuzu altında bulunan (38) Max Rumpf, muhtelif yazlarda (39)hukukun tatbikî metodu hakkmda tecribe yapmıstar. Hâkimin bir tatbik ve dedüksiyon makinesinden başka bir şey olmadı̆̆ hakkındaki ananavî talâkkinin çürüklüğì onun tarafindan ortaya konmaktadır. $O$, umumiyetle mûtadolan tefsir kaidelerinin ve-terkỉbî sanatlann (Konstrukitonskünste) kısmen yapma kısmen de çürǜk olduğu anlaşılmıştır, diyor. Hâkim sirf fikrî bir mantığa göre hüiküm verenden daha fazlabir kimsedir; o, taktir edici bir kimsedir; ayni zamanda kıymet hükümleri ve irâde karariarı verir(Rǜmelin). Bu itibarla o, vazifesine bin tarafl dumaği bir terbiye, fikrî tahsil ile ehliyet iktisabetmig olmaz: Asıl mesele, iradî kültür, amelî göriißs ve takt, sahtiyettir. Adıckes'in kastettiği mânâda hâkim şahsiyeti lâzımdır(40).

7 . Staffel'in beyanats da Windelband ve Rickert'in kuvvetli- tesirlerini göstermektedir(41). Bütün hukuk kaideleri, kıymet hükümlerine istinat ederler. Bütün kıymet hükiumlerinin esası gaye ve vasıta münasebetidir. Bundan dolayı hukukî kaidelerin şümulü, onlara hâkim olan gayelerin tahkiki ve bu gayelere vïsule hadmolan vasitalarm tetkiki ile bulunur. kanunu vaktiyle koymuş olan kimsenin gayevî mülâhazalarna hâkim bağlıdır. Bu mülâhazalar, zamanın tahavvülï ile mânâlarmı kaybetmiş olsalar dahi hâkim onlara riayetle mükelleftir: Tashih yollu bir kanun tefsirinden hâkím memmûdur.

8. Erich Jung, çok defa' Schopenhauer'a imtisâlen yalnzz kanunun boşluktian âri olduğu akidesiyle enerjik bir muicadele değil; hukukun müisbetliğini de tenkidli surotte tetkik etmis, bilhasea "Tabiil hukik kaideleri" mefhum ve mahiyetini derin bir tahlile tâbi tutmuştur(42). Bư zat; ya-

(37)* Wustendörfer buna: yakin fikir cereyanları takib. eder. Arch. Civ: P., 110 (1913), 219 ff. Bak. Heck, Gesetzesauslegung, s. 284.

(38) Windelband, Geschichte und Naturwissenschaft; 3 . Auflage, 1904; Rickert, Kulturwissenschaft und Naturwissenschaft, 1899.

(39) Gesetz und Richter, 1906 (bu bapta Reichel, Rein. Zeitschr., 1909, 154), . Der Strafrichter I, 1912, II, 1913. - Dr, Pfenniger'in şahsi hücumlaria tuzlanmıs. tenkidine (Schweiz. Jur. Zeit; 1913, 128) objektif kıymet tanyamam.

(40) Buna benzer, fakat pek az derinleştirilmiş, ve pek. az vázh kaleme alımış fikirler Wurzl'de bulunur, Das juristische Denken, 1904 :

(41) Die Steliung des Richters gegenuber dem Gesetz, Deutsche Richterzeitung, 1911, 724 ff.

(4.2) Die logische Geschlossenheit des Rechts 1900; "Positives" Recht 1907 (bu bapta Reichel, Kr. V. J. Schr. 3. Folge, Bd. 12, s. 437); das Problem des naturlichen Rechts, 1912 (bu bapta Reichel, Lit. C. Bl. , 1912, 1650). 
zll hukuktan baskka yazll olmiyan hukuk da vardır. Ve somuncusu, birincisi kadar aym müsbetliği haizdir, der.Mer'i hukuk ve doğru hukuk aslında aym mefhumlardır. Umumun yanls bulduğu bir "Hak", bu suretle müsbetliğini de kaybetmiş olur.Bu suretle Jung, eski tabiî hukukun bazl saik fikirlerine, açıkça itiraf da ettiği üzere, tekrar imtisâl etmiş bulunmaktadır (43), 一şüphesiz Stammler'den tamamen başka bir mânâda.

9. Bahis mevzuu meseierle uğraşan meslekî feylozoflar arasında Oskar' Kraus ve Emil Lask'ı zikretmek lâzımdır.

Kraus, küçük ve fakat mühteva itibariyle mühim olan muhtelif yazliamnda(44) Aristo'nun nazariyeierine dikkat çekmis ve bazı serbest hukukçular tarafindan arzu edilen tefsir metodunun büyük hakîm tarafindan daha vaktiyle tamamiyie gösterilmiş oduğunu izaha teşebbüs etmiştir(45). Bundan başka Kraus bir çok defa Bentham, Mill, Jhring gibi faidecilerin ileri sürmüs olduklam noktai nazarlara istinad etmektedir. Ona göre kanun, jetimaî refaha ve kültürün tealisine ulaştıracak bir vasitadır. Kanun böyle bir vasıta oimak üzere talâkki vetefsir edilmek lâzumdir. Bu tefsir mümkün olmaz ve kanuna göre hüküm verme açıca bir adaletsizlik olursa zaruret haijnde kanuma muhalif olarak da karar verilebilir; yâni kanun koyan hazır olsaydı o da böyle hükmederdi diye kabul edilmek lâzımgelir.

Lask (46) Israr ile bütïn hukukun gayevî bünyesine, tabiî ilimlere muiteallik mantık vasitalariyle onun ilmî surette idrak ve ihatası mümkiłn olmadiğına işaret eder. Hukuka salih olan şeyler hukukî fikir itibariyle bir derece gayevî bir nesce bürünür. Hukukda mantıkcılık onun amelilik ile kaynaşması olarak anlaşılmalıdır. Hukuk ve kanun birbirile intibak halinde değildir. Kanun - örf ve âdet hukuku, mahkeme teamülü vesaire - ancąk jurisprudans'in mer'i müsbet hukuku kısmen yaratıcı mesai ile kendilerinden istihsal etmesi lâzım gelen karinelerden (Indizen) biridir.

III - Bununla listeyi kapamak istiyorum. Bunun natamam olduğunu daha önce söylemiştim. Bazı kıymetli isimler eksiktir. Fakat bir bibliyografi vermek benim işim değildir. Madde (sachlich) itibariyle her noktada tafsilâta da girişemedim. Maksadım yalnızca rehberlik edecek noktainazarların kısa bir krokisini yapmaktır (47).

(43) Bak. Kezalik Pitreich, Osterreich. Zentraibatt für Notariat, 1910 s. 98.

(44) Bak. bilhassa Grïnhuts Zeitschrift, 32, 613

(45) Bak, keza Kiss, Archiv für Rechts-und Wirtschaftsphilosophic: 1910, $536 \mathrm{ff}$.

(46) Rechts philosophje, 1905 (aus der Heidelberger Festgabe für kuno Fischer).

(47) Avukat Ernest F'uchs'un polemik yazları zamanları için ehemmiyeti ha- 
1. Geriye bir bakış göstereceği üzere isimleri geçenler arasında çok fikir ihtilâflar vardır. Takribî ihtilâf hemen hemen ancak menfi bakımdandır. Pozitif bakımdan yollar ve kısmen de gayeler ikiye aymlır. Ancak iki noktainazar birleștirici bağ olarak kabul edilebilir; yâni menfi istikamette kanunun mutlak kifayetinin reddi ve bu kifayetin temeli izerine kurulan kontsruktiv tefsir nazariyesinin reddi, fakat pozitif noktainazardan, kanun kuvveti ile hâkimlik arasında hâkime daha müsait bir çember çizme lüzumu ve bununla ilgili olarak hâkimin faaliyetini kanun koyanm ve idare memurlarmin faaliyetine yaklasstırmak kaziyesi.

Yukarda bahsedilen müelliflerin ne derece serbest hukukçu olarak gösterileceği veya, gösterilmiyeceği işbu pek mühim tâbire verilecek çerçeveye tâbidir. Ancak bu tahdit, hiç bir vakit muvaffakiyetle yap1lamadığından su veya bu müellifin serbest hukukȩu olup olmadığı hakkındaki münakaşa sırf terminolojik bir kıymeti haiz olacaktır. Bundan başka yukarda adları geçen müelliflerden coğunun, kendilerinin hakikî serbest hukukçular arasında saylmalarma sarahaten itiraz ettikleri de kaydolunmak icabeder.

2. Bir kimsenin serbest hukukçu olup olmadığının tâyini kolay olmayinca serbest hukuk doktrinleri içinde hangi istikamete mensup olduğu sualini cevaplandırmak büsbütün güçlïk arzeder. Aralarnnda kısmen kuvvetli kavgalar yapan serbest hukuk hocalarm bijyük gruplara ayırmak için radikal ve mutedil serbest hukukçular farkından bahsedilmiştir. Fakat hangi unsurlarin radikalizm saylacağ hakkında her vakit kâfi bir vüzuh elde etmek kabil değil gibi görünür. Cok kere şekil ve esas (Sache) karıştırılmaktadır. Bazı serbest hukukçular gürültüler çkardular (48); Birçoklart bunlara "Radikaller" demek isterler. Fakat günlük gürültülerden uzak ve sessizce işlerini gören ve iddiasıı, ilmî surette kendi isteklerini formüle eden diğer mutahassıslar ileri gitmiyorlar mı? Yalnız ses kuvveti birşey ifade etmez.

(Devami Var)

1zdir. Bu mulellifin kuvveti hakikî veya mefruz fenalıkları ortaya koymaktan ibarettir. Bu kabil hallerde şiddetli bir ifade tarzi kullanmaksızın daima bir başarı olamyacağ işin mahiyeti icabıdır. Tenkitçi karakterde olan bu mutcadeleci mu. hariir pozitif bir inşaya müsteid degildi. 1906 da Gräus Flavius mùstear namı altında neşredilen programindan ileride bahsedilecektir. Bir tarih izahı çerçevesi içinde bu yazının fikrimce de derin bir ehemmiyeti yoktur. Surf vesilevi suretteki hâdiselere kati bir ehemmiyet atfetmek daláletinde bulunulursa tarihi seyrin esas kısımları anlaşılmamıs olur. Hiç bir ciddi tarihçinin, otuz sene muharebesinin sebep ve mânâsını imparatoriuk murahhaslarmın meşhư pencereden skutundan istihraç etmek aklina gelmez.

(48) Bunlarm bu suretle kendi işine ne kadar zarar verdikleri mulkerreren dogrru olarak tebarïz ettirilmiştir; bak, Rogge'nin Zur Kritik des Rechts, 1911, s. 2. 